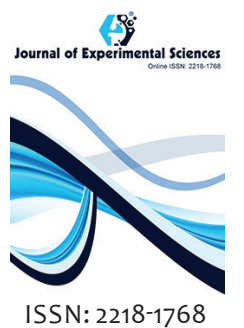

Received: March 03, 2018 Accepted: May 10,2018 Published: May 16, 2018

*Corresponding Author: Rajesh K. Jadhav Email: rajesh.jadhav@ ruparel.edu

\section{Study of yeast quality enhancement by Forage Deproteinised Juice (DPJ) fermentation}

\author{
Rajesh K. Jadhav*1 and Sayali Deshmukh² \\ Department of Botany, D.G. Ruparel College, Mumbai, Maharashtra 400 016, India, ${ }^{2}$ Research Laboratory, \\ Department Of Botany, D. G. Ruparel College,Mumbai, Maharashtra 400 016, India
}

\begin{abstract}
Process of green crop fractionation (GCF) was considered and its byproducts were tested for evaluation. The byproducts obtained were pulp, LPC (Leaf protein concentrate), Juice, Deproteinised juice and pressed crop (PC). The dry weight of LPC from each crop was measured. Maize forage LPC was more as compared with other forages. Deproteinised Juice (DPJ) is utilised as a medium for the fermentation of yeast. This yeast growth was compared with the yeast grown on Hansens broth media as control. Various concentration ratios of DPJ and Hansens media were prepared and yeast was fermented. Yeast mycelia grown on DPJ was found higher as compared with other concentrations. The culture filtrates of yeast mycelia collected and used to study the enzyme invertase by immobilisation method and the presence of alcohol was by iodoform test. Almost all the samples of various concentrations showed the presence of alcohol by proper secretion of enzyme zymase. Enzyme invertase appropriately found less in the culture filtrate of yeast mycelia grown on DPJ alone. Therefore DPJ is responsible for less breakdown of sucrose as compared with Hansens media which breaks down more sucrose into glucose and fructose by the enzyme invertase.
\end{abstract}

KEYWORDS: LPC, DPJ, hansens broth, yeast, invertase, alcohol

\section{INTRODUCTION}

In leaf protein (LP) research, during the process of green crop fractionation (GCF), the pulp is obtained [1].This pulp is squeezed to obtain the juice. This juice is heated to $90^{\circ} \mathrm{C}$ to coagulate the proteins to form the precipitate. The supernatant obtained is deproteinised, is filtered by filter paper. The residue obtained is called LPC (Leaf protein concentrate), as the byproduct. This byproduct is used for malnourishment of rural children $[2,3]$. The supernatant Deproteinised juice (DPJ) obtained after filteration is disposed randomly. Therefore to avoid pollution because of its disposal, its proper usage is advisable. It contains $70 \%$ of carbohydrates along with vitamins and minerals $[4,5]$.This can be used as manure or growing different economically important fungi [6,7]. Even it can form good quantity of metabolites [8]. Fresh juice during previous investigation when used for fermentation, secretes hydrolytic enzymes and effects on the yields of LPC [9].

During present investigation the LPC obtained is measured in three crops [10,11 and 12]. Priority was given to fodder crops for the purpose to suggest to use it in industries, because of its wide availability. Previously, Yeast fermentation on DPJ was compared with Glucose nitrate (GN) medium and the hydrolytic enzmes were studied from each [13]. Presently, the DPJ obtained from forages of the three crops were utilised for fermentation of yeast to release enzymes invertase and zymase and compared with the traditional Hansens broth media used in laboratory at different concentrations. The culture filtrates obtained of the yeast mycelia grown on DPJ are employed to study of the enzyme invertase $[14,15]$ and production of alcohol [16].

\section{MATERIALS AND METHODS}

Fresh Deproteinised juice obtained from the crops of wheat (Triticum vulgare L), Maize (Zea mays L) and Potato (Solanum tuberosum L) were used for the growth of yeast (Sacchomyces cerevisiae). During GCF, the LPC obtained is dried in hot air oven and the weights were measured. The yeast suspension was inoculated in DPJ prepared of different concentrations along with Hansens broth as control in aseptic conditions in inoculating chamber and allowed for fermentation for 8 days at room temperature of $32^{\circ} \mathrm{C}$ in laboratory. After 8 days, the mycelial DPJ is filtered by whatman filter paper no.l and the culture filtrate obtained are collected and utilised for the study of enzyme invertase. The mycelia obtained on filter paper is dried along with filter paper is dried in hot air oven.

Copyright: $\odot 2018$ The authors. This article is open access and licensed under the terms of the Creative Commons Attribution License (http://creativecommons.org/licenses/by/4.0/) which permits unrestricted, use, distribution and reproduction in any medium, or format for any purpose, even commercially provided the work is properly cited. Attribution - You must give appropriate credit, provide a link to the license, and indicate if changes were made. 
Hansens broth: Glucose, $50 \mathrm{~g}$; peptone, $10 \mathrm{~g}$; $\mathrm{K}_{2} \mathrm{HPO}_{4}, 3 \mathrm{~g}$; $\mathrm{MGSO}_{4} 7 \mathrm{H}_{2} \mathrm{O}, 4 \mathrm{~g}$ and Agar $20 \mathrm{~g} / 1000 \mathrm{ml}$.

Iodoform test: $1 \mathrm{ml}$ of iodine solution was added and diluted to sodium hydroxide solution drop wise until brown colour discharges, then heated to form yellow coloured precipitate.

Invertase activity method: The experiment was performed by immobilisation of yeast cells by entrapping in calcium alginate and activity of enzyme invertase measured by beads. After removal of beads, $0.5 \mathrm{ml}$ of copper sulphate was added. After heating, effervescence stops when $0.5 \mathrm{ml}$ phosphomolybdic acid was added. Gradual increase of O.D was measured at $660 \mathrm{~nm}$ after appearance of blue colour. Enzyme activity increases as the immobilized number of beads increases. Standard graph was plotted to obtain multiplication factor to calculate $\mathrm{mg} / \mathrm{ml}$ of enzyme.

\section{RESULTS AND DISCUSSION}

Table 1 and figure 1 (graphical presentation) indicates that as LPC (Leaf protein concentrate) prepared from maize by green crop fractionation (GCF) was responsible to get more in dry weight i.e. $6.044 \mathrm{~g}$ as compared with Solanum tuberosum and wheat LPC.

Table 2 and figure 2 (graphical presentation) indicates the comparison of the yeast mycelial biomass obtained on Deproteinised juice (DPJ) fermentation and the fermentation of yeast done on Hansens broth media.It was observed that, DPJ was responsible to enhance the mycelial biomass as compared with Hansens broth media. It was more in all DPJ used namely from wheat, maize and potato forages. When we compare the DPJ among all, which enhanced more mycelia, that was potato DPJ, i.e. $1.007 \mathrm{~g}$. The statistical mean of table 2 indicates the growth of yeast mycelia was more on Solanum tuberosum leaves DPJ as compared with maize and Triticum leaves DPJ.

When different concentratons of DPJ were utilised for the yeast fermentation and along with it when Hansens broth was also used at different concentrations, there were different results. It was observed that when the concentrations of DPJ enhanced in $50 \mathrm{ml}$ of medium, which was consisting of reducing concentrations of Hansens broths i.e. DPJ: Hansens broth in $\mathrm{ml}$ (10: 40, 20:30, 30:20 and 40:10), it was observed that, there was the reduction of mycelial dry weight of yeast, showed by all DPJ, showed in Table 2. However also of decreasing concentrations of Hansens medium decreased MDW. Therefore it concludes that the concentration of DPJ and Hansens broth should be used appropriately for good result of mycelial biomass of yeast. The appropriate concentration for good mycelial biomass was found in the concentration ratio of DPJ: Hansens broth was 10:40.

Overall statistical mean of Table 2 indicates that the DPJ made up of potato forage showed appreciable growth of yeast mycelia as compared with two monocot forage DPJ of wheat and maize. As compared with maize, wheat forage DPJ showed increased mycelial weight of yeast. While maize forage DPJ, was not found as feasible as the other two DPJ to induce mycelial growth of yeast. Maize DPJ was responsible to give appreciable growth when used without combination of Hansens media.
Table 1: Preparation of Leaf protein concentrate (LPC) by Green crop Fractionation (GCF)

\begin{tabular}{lc}
\hline Crop/22g pulp & LPC (g) \\
\hline Triticum vulgare & 4.443 \\
Maize & 6.044 \\
Solanum tuberosum & 5.718 \\
\hline
\end{tabular}

Table 2: Effect of fresh DPJ as a medium from different forages by GCF and Hansens media on Yeast growth fermentation to release enzyme zymase

\begin{tabular}{lccc}
\hline Medium (\%) & \multicolumn{3}{l}{$\begin{array}{l}\text { Mycelial Dry weight (MCW in g) of } \\
\text { yeast }\end{array}$} \\
\cline { 2 - 4 } & Triticum & Maize & Solanum \\
\hline Control (Hansens Broth alone) & 0.194 & 0.15 & 0.466 \\
DPJ (alone) & 0.089 & 0.321 & 1.007 \\
10:40 (DPJ : Hansens Broth) & 0.264 & 0.132 & 0.377 \\
20:30 (DPJ : Hansens Broth) & 0.239 & 0.109 & 0.346 \\
30:20 (DPJ : Hansens Broth) & 0.166 & 0.039 & 0.542 \\
40:10 (DPJ : HansensBroth) & 0.072 & 0.341 & 0.017 \\
Mean & 0.166 & 0.123 & 0.522 \\
Coefficiant of variation & 51.80 & 97.56 & 54.21 \\
\hline
\end{tabular}

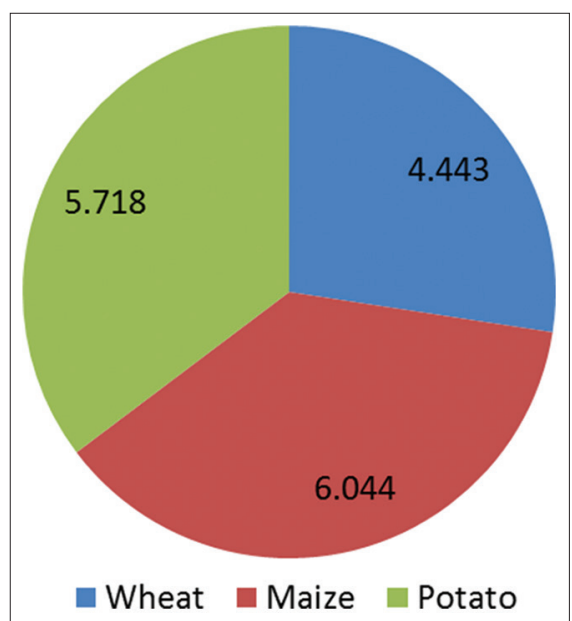

Figure 1: Dry weights of LPC (g) by green crop fractionation of three different crop forages

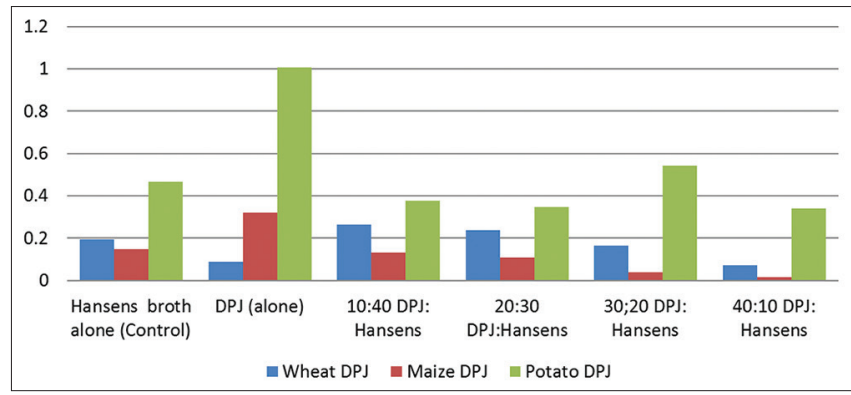

Figure 2: Effect of fresh DPJ from different forages by GCF and Hansens media and their ratios of various concentrations on yeast growth $(\mathrm{g})$

Table 3 indicates the more invertase enzyme presence in culture filtrates of yeast mycelia grown on Hansens broth i.e $222 \mu \mathrm{g} / 100 \mathrm{ml}$. It means breakdown of sucrose to glucose is more activated by Hansens broth. Majority of the fruits consists of 
Table 3: Effect on Invertase activity from various culture filtrates of yeast grown on DPJ and Hansens broth media and their concentration ratios

\begin{tabular}{lccc}
\hline Medium (\% in ml) & \multicolumn{3}{c}{ Enzyme Invertase $(\mu \mathrm{g} / 100 \mathrm{ml})$} \\
\cline { 2 - 4 } & Maize & Triticum & Sol anum \\
\hline Control (Hansens broth) & 183 & 222 & 225 \\
DPJ (alone) & 153 & 039 & 108 \\
10:40 (DPJ: Hansens) & 096 & 018 & 207 \\
20:30 (DPJ: Hansens) & 078 & 186 & 072 \\
30:20 (DPJ: Hansens) & 042 & 081 & 084 \\
40:10 (DPJ: Hansens) & 018 & 042 & 066 \\
Mean & 77 & 73 & 107 \\
Coefficient of Variation & 67.61 & 91.82 & 51.15 \\
\hline
\end{tabular}

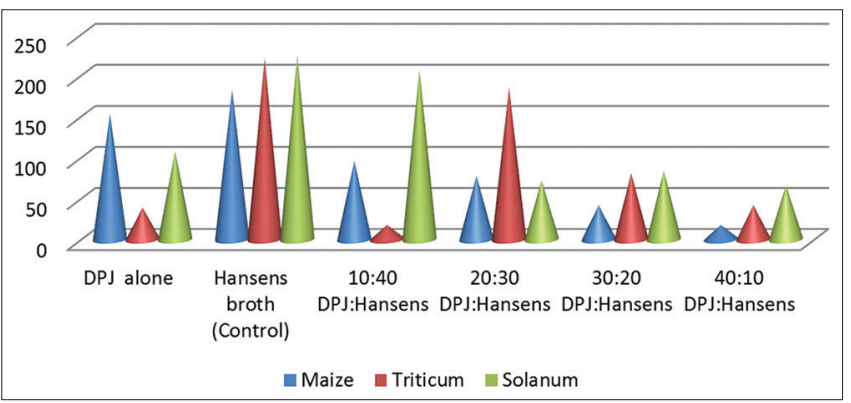

Figure 3: Effect on Invertase activity $(\mathrm{mg})$ from various culture filtrates of yeast grown on DPJ and Hansens broth media and their concentration ratios

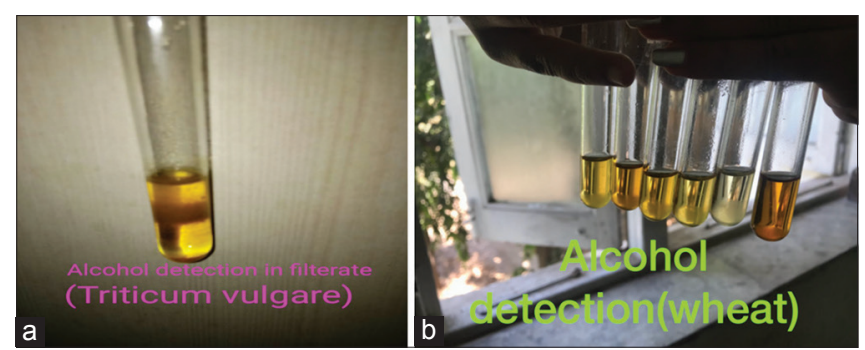

Figure 4: Alcohol detection by iodoform test in the culture filtrate of yeast grown on a) Triticum vulgare forage DPJ and b) At various concentration ratios of Triticum DPJ : Hansens broth

sucrose, thus DPJ performance also indicates retaining sucrose, as it is the leafy source. Therefore less invertase enzymes in $39 \mu \mathrm{g} / 100 \mathrm{ml}$ because of Triticum DPJ as a medium investigation was found beneficial in this research. Figure 3 indicates the enhanced concentrations of DPJ along with Hansens broth combination, reduced the rate of invertase enzyme activity. Despite of Hansens medium addition in DPJ, the rate of invertase enzyme activity was less. Therefore it seems DPJ was effected dominantly.

Figure $4 \mathrm{a}$ and $\mathrm{b}$ indicates the alcohol production by yeast by iodoform test in the cuture filtrate of wheat forage DPJ. The darkness of yellow colour in culture filtrate indicates more presence of alcohol by yeast grown on DPJ medium alone and at various concentrations along with combination of Hansens broth as mentioned in previous tables no. 2 and 3. Hansens broth alone when used for yeast fermentation, its culture filtrate showed faint yellow colour by iodoform test as compared with the DPJ used. Same performance of alcohol presence showed by DPJ made from forages of maize and potato by iodoform test as showed figures $\mathrm{a}$ and $\mathrm{b}$.

\section{CONCLUSION}

By the process of GCF, LPC prepared from maize leaves pulp was found more as compared with Solanum tuberosum and wheat leaves. The table 2 graphical presentation and statistical analysis indicates that, as compared with the Hansens media, yeast grown favourably on all DPJ from various forages. Hence DPJ alone itself enhances the mycelial biomass of yeast. And there was reduction of mycelial biomass when the concentrations of Hansens medium is reduced. There was reduction in mycelial biomass of yeast when the concentrations of DPJ enhanced. But when DPJ used alone for yeast fermentation, the mycelial dry weight was enhanced.Therefore proper concentration of DPJ to be used is advisable. DPJ reduced the enzyme invertase is beneficial as it is responsible to stabilise the sucrose of yeast neglecting the breakdown to glucose and fructose in less amount as it is the forage source. Therefore because of DPJ the food quality of yeast enhanced. Yeast fermentation done by DPJ of all forages used viz Triticum, Maize and Solanum tuberosum, produced the alcohol in similar amount, when compared with the fermentation done on Hansens medium, by the iodoform test.

\section{ACKNOWLEDGEMENTS}

The author thanks for the inspiration of research and express deep sense of gratitude to Professor A.M. Mungikar, Dr. Babasaheb Ambedkar Marathwada University, Aurangabad and Editor, Bioinfolet, the quarterly Journal of Life Sciences. Thanks are also to D. G. Ruparel College, Mumbai to provide laboratory facilities.

\section{REFERENCES}

1. Rajesh K Jadhav. Studies on the preparation of Protein concentrates from green leaves. Ph. D.Thesis, 1997. Dr. B.A. M. U. Aurangabad, Maharashtra,India

2. Ream HW Jorgensen NA, Koagel RG and Bruhn HD. In Leaf protein Concentrates. 1983. (Telek. L. and Graham, H.D. Ed), AVI Publishing Co.,Inc., Westport, Connecticut: 467.

3. Sayyed. Illiyas. Chemical composition of LPC and PCR prepared from lucer ne (Medicago sativa. Linn). Scholarly Articles In Botany. 2011; 154 - 159.

4. Yoshida. S, Taguchi H, Muranaka M, Ukai K, Kawamura Y. Investigation Of biologically active substance in deproteinized juice alfalfa by Lemna assay test.Japanese Journal of Soil Science and Plant Nutrition. 1995; 66; (5): $566-571$.

5. Rajesh K. Jadhav. Distribution of Ash, Calcium and Phosphorus in the Byproducts Of Green Crop Fractionation. International Journal of Bioassays.2015 4.9: 4329 - 4332.

6. Mungikar AM, Jadhav RK. Yeast Biomass Production on Deproteinised Leaf Extracts. Geobios. 2005; 32; (1): $101-102$.

7. Sayyed IU. Fungal biomass production using Deproteinised leaf juice (DPJ) Of Trigonella foenicum graceum. L. International Journal of Bioassay. 2015. 4 (12): 4643 - 4649.

8. Sayyed IU. Deproteinised leaf Juice as a medium for microbial growth and $\alpha$ Amylase production. International Journal Mendal. 2003 a.20; $(3-4): 79$.

9. Rajesh K Jadhav. Effect of Amylase and Protease enzymes on the yields of Leaf protein Concentrates (LPC) prepared by Fermentation 
of leaf Juice. Indian Journal of Plant Sciences (CIBTech).2018 a; 7;(1): 42-52.

10. Ohshima M, Proydak NI, Nihino N. Effect of addition of lactic acid bacteria or previously fermented juice on the yield and the nutritive value of alfalfa (Medicago sativa) leaf protein concentrate coagulated by anaerobic fermentation, Animal Science and Technology.1997; 68;(9):820 - 826.

11. Jadhav RK AM. Mungikar. Preparation of Leaf Protein Concentrates (LPC) J.Geobios. 2001: 2, 28; (4):101- 102

12. Sayyed IU. Chlorophyll content in leaf protein concentrate prepared from lucerne Juice. Bioinfolet, The Quaterly Journal of Life Sciences. 2003 b; $1 ;(1-4): 49$.
13. Rajesh K. Jadhav. Yeast utilizing deproteinised leaf juice (DPJ) as a medium for growth and production of metabolites. Plant Archives, An International Journal. 2018 b; 18: 2

14. T. Roitsch ME, Balibrea M, Hofmann R, Proels AK. Sinha Extracellular invertase: key metabolic enzyme and PR protein.Journal of Experimental Botany. 2003;54; (382): 513-524

15. Moharib SA. Yeasts utilizing deproteinised leaf juice medium for production Of protein and polysaccharides. Advances in food Sciences. 2006; 28, (2): $79-84$.

16. Leonora A, Hohl MA Joslyn. Lactic acid formation in alcoholic fermentation by yeast. Plant Physiology.1941;16; (2): 343-360. 